УДК 336.762

JEL classification: E44, E49, F01, F02

Редько О.В.

Головний консультант відділу соціальної стратегії

центру економічних та соціальних досліджень ORCID ID: 0000-0002-0434-0534

Наиіональний інститут стратегічних досліджень

Гаркавенко В.O

ORCID ID: 0000-0003-0508-594X

Національний технічний університет України «Київський політехнічний інститут імені Ігоря Сікорського»

\title{
ВПЛИВ ПАНДЕМІЇ COVID-19 НА СТАН ТА ПЕРСПЕКТИВИ РОЗВИТКУ МІЖНАРОДНОГО ФОНДОВОГО РИНКУ
}

\section{THE IMPACT OF THE COVID-19 PANDEMIC ON THE STATE AND PROSPECTS OF THE INTERNATIONAL STOCK MARKET}

Актуальною є проблема прогнозування майбутніх перспектив ринку цінних паперів світу та визначення иляхів виходу з кризи та стабілізації ситуації, а також визначення виграшних можливостей для Украӥни. У статті розглянуто сутність міжнародного фондового ринку як складової фінансового сектору економіки. Досліджено його сучасний стан і перспективи розвитку. Описано, щзо на розвиток міжнародного фондового ринку негативний вплив мають такі фактори: державний контроль та лімітування, оподаткування в країнах імпортерах, складність взаємних розрахунків тощо. Досліджено зміни на ринку цінних паперів, викликані пандемією COVID-19. Виявлено основні проблеми та перспективи їх вирішення, а також можливості для Украӥни. Сучасні міжнародні ринки иінних паперів розвиваються у напрямку глобалізащії, інституціоналізації, технологізації, скорочення кількості фондових бірж до однієї для країни, дематеріалізації та електронного обігу цінних паперів тощо. Капіталізація міжнародного фондового ринку зросла на $\$ 17$ трлн. за 2019 рік. В Україні спостерігається тенденція до зниження доходності державних облігацій. Стрімко розвивається інтернет-трейдинг на світових біржах. У 2019 вперше почали надавати онлайн доступ до торгів на Украӥнській біржі. Продемонстровано, щуо міжнародний ринок иінних паперів полегшує господарським суб'єктам доступ до міжнародного ринку вільних капіталів. Наукова новизна публікації полягає у дослідженні впливу пандемії COVID-19 на ситуацію на міжнародному фондовому ринку. Одним з найбільш яскравих показників обвалу $\epsilon$ зниження вартості ф'ючерсів на нафту до від'ємного значення. Тому Україна може використати свої можливості для зберігання нафти світової арени з метою отримання прибутку.

Ключові слова: фондовий ринок, цінні папери, фінанси, біржа, фінансовокредитні інститути, міжнародна торгівля, державні облігації, пандемія, COVID-19 
The problem of forecasting the future prospects of the world securities market and identifying ways out of the crisis and stabilizing the situation, as well as identifying opportunities for Ukraine is relevant. The article considers the essence of the international stock market as a component of the financial sector of the economy. Its current state and prospects of development are investigated. It is described that the development of the international stock market is negatively affected by the following factors: state control and limitation, taxation in importing countries, the complexity of mutual settlements, and so on. The changes in the securities market caused by the COVID-19 pandemic have been studied. The main problems and prospects for their solution, as well as opportunities for Ukraine have been identified. Modern international securities markets are developing in the direction of globalization, institutionalization, technology, reducing the number of stock exchanges to one for the country, dematerialization and electronic circulation of securities and more. The capitalization of the international stock market increased by \$17 trillion. for 2019. In Ukraine, there is a tendency to reduce the yield on government bonds. Internet trading on world exchanges is developing rapidly. In 2019, for the first time, online access to trading on the Ukrainian Stock Exchange began. It has been shown that the international securities market is a factor that accelerates the global process of economic growth, facilitates access to the international market of free capital for various economic entities. The scientific novelty of the publication is to study the impact of the COVID-19 pandemic on the situation on the international stock market. One of the most striking indicators of the collapse is the decline in the price of oil futures to a negative value. Therefore, Ukraine can use its opportunities to store oil on the world stage for profit.

Keywords: stock market, securities, finance, stock exchange, financial institutions, international trade, government bonds, pandemic, COVID-19

Вступ. У сучасних реаліях цивілізованої ринкової економіки фондовий ринок відіграє вирішальну роль у консолідації національної економіки загалом та в розвитку промислового сектору зокрема. Це найбільш динамічна та організована складова ринку капіталу. За останні 20 років минулого століття спостерігалося значене розширення фінансових ринків в розвинутих країнах та країнах, що розвиваються. Для останніх фондові ринки відіграють важливу роль у формуванні рівня капіталу за рахунок ефективної мобілізації заощаджень та забезпечення інвестиційної безпеки. Для країн 3 перехідною економікою була характерною поява, а точніше відтворення, сектору фінансових ринків. Оборот торгівлі акціями на світових біржах протягом останніх 20 років збільшився у вісімдесят разів, показник ліквідності ринку акцій зріс до $125 \%$ [1].

У зв'язку з постійним технологічним прогресом у сучасному світі структура ринку цінних паперів стала набагато складнішою 3 погляду використовуваних інструментів. Розвиток інтернет-технологій дозволяє сьогодні здійснювати мільярдні операції за декілька секунд, що значно підвищило волатильність світового фондового ринку. Ринок цінних паперів до 1940-х років був обмежений масштабами розвинутих країн Свропи, Північної Америки і Австралії. На Сполучені Штати припадає 
приблизно 40\% від світового ринку акцій, облігацій і деривативів, а на країни "великої вісімки" близько 60\%, проте не зважаючи на випереджаючі темпи зростання ринків частка їх у світовому ринку цінних паперів не більша $10 \%$ [1].

Постановка завдання. Фондовий ринок є основним механізмом перерозподілу грошових накопичень. Тому важливим $\epsilon$ розкриття сутності поняття «міжнародний фондовий ринок», огляд його функцій, структури та етапів формування для подальшого аналізу.

Пандемія COVID-19 у 2020 році призвела до стрімкого обвалу на світових ринках, в тому числі і фондовому. Актуальною $є$ проблема прогнозування майбутніх перспектив ринку цінних паперів світу та визначення шляхів виходу з кризи та стабілізації ситуації, а також визначення виграшних можливостей для України.

Методологія. У статті були використані наступні методи: класифікаційно-аналітичний, аналізу та синтезу, логічного узагальнення.

Результати дослідження. Міжнародний фондовий ринок - це сфера економічних відносин, які виникають між суб'єктами різних країн 3 приводу здійснення операцій 3 цінними паперами, що випускаються на одному або декількох іноземних (стосовно країниемітента) ринках, і знаходяться поза юрисдикцією певної країни. Відповідно, цінні папери, які обертаються на міжнародному фондовому ринку, $\epsilon$ іноземними (якщо випуск іде на одному ринку) або міжнародними (якщо випуск здійснюється одночасно на декількох ринках). Міжнародний фондовий ринок - це по суті надбудова над національними фондовими ринками, які складають його основу.

Міжнародні фондові ринки концентруються у міжнародних фінансових центрах - місцях зосередження спеціалізованих фінансовокредитних інститутів. Залежно від обсягів операцій, спектра інструментів, валютного законодавства та інших факторів розрізняють фінансові центри місцевого, регіонального та світового рівнів. У міжнародних фінансових центрах здійснюються міжнародні валютні, кредитні, фінансові операції, угоди з цінними паперами, золотом. До них належать Лондон, Нью-Йорк, Токіо, Сингапур, Гонконг, Франкфурт-на-Майні, Цюрих, Бостон, Сеул, Чикаго та ін. Історично вони виникли на базі національних ринків, а потім розвинулися на основі світових валютних, кредитних, фінансових ринків, ринків золота.

До 2019 року найбільшим фінансовим центром у світі вважався Лондон. Але тепер цю позицію зайняв Нью-Йорк. В першу чергу, Brexit спричинив такий перерозподіл сил на світовій арені. Про це свідчать результати опитування топ-менеджерів фінансового сектора, проведеного консалтинговою компанією Duff \& Phelps [2]. 
Нью-Йорк визнали провідним світовим фінансовим хабом 56\% респондентів, тоді як Лондон лише 34\%. Позиції Лондона в порівнянні з 2018 роком погіршилися на 19 процентних пунктів (п.п.), Нью-Йорка - покращилися на 14 п.п.

Найбільш перспективними топ-менеджери вважають азіатські фінансові центри. Майже кожен п'ятий респондент прогнозує, що вже через 5 років азіатське місто очолить рейтинг найважливіших фінансових центрів. Оптимістично оцінюються можливості Шанхаю, який, як очікується, в майбутньому випередить Сінгапур і Гонконг.

Міжнародний фондовий ринок сформувався в результаті масового вивезення капіталу, перш за все з тих країн, які $є$ власниками найбільших ТНК та банків. Його формування прискорене такими процесами: науково-технічним прогресом; розвитком інтеграційних процесів; успіхами у розвиткові банківської та біржової справи; введенням спільних багатонаціональних валют; певною стійкістю валютних курсів; збільшенням кількості проектів, що передбачають використання капіталу різних країн [1].

На розвиток міжнародного фондового ринку негативний вплив мають такі фактори: державний контроль та лімітування, оподаткування в країнах імпортерах, складність взаємних розрахунків тощо. Проте більшість країн визнають та розуміють важливість міжнародної торгівлі цінними паперами як інструменту для міждержавного переливання капіталу. Тому ці проблеми вирішуються за допомогою дво- і багатосторонніх угод та удосконалення механізму розрахунків.

Міжнародний фондовий ринок існує вже більше 150 років і пройшов декілька етапів розвитку:

Перший етап охоплює період до Першої світової війни. В цей час емісії облігацій іноземних емітентів, які потребували фінансових ресурсів, мали епізодичний характер. Так, у XVII ст. у Лондоні вже існував досить активний ринок цінних паперів, який вже був міжнародним і на якому реалізовувалися державні облігації, акції та ануїтети. Будівництво залізничних доріг та Суецького і Панамського каналів у другій половині XIX ст. викликало створення акціонерних товариств, акції яких продавались на Лондонській, Нью-Йоркській, Амстердамській, Паризькій, Франкфуртській, Віденській та інших біржах.

Масове створення акціонерних товариств, що будували та експлуатували залізниці в різних країнах, вважається вирішальним фактором, який стимулював формування масштабних ринків акцій, швидкий розвиток міжнародного ринку цінних паперів та зростання обсягів на ньому. У 1912-1913 рр. обсяги операцій з цінними паперами досягли (в середньому для всіх країн світу) 16,4 \% світового ВВП, у 
тому числі у Великій Британії - 41, Франції - 26, США - 19, Німеччині $-11 \%$.

Другий етап охоплює період активного формування світового господарства, коли встановлювалися міцні зв'язки між промислово розвинутими країнами. В цей час фіктивний капітал мав чітко виражену національну належність. Акумуляція акціонерних капіталів корпораціями розвинутих країн привела до того, що вони активно почали інвестувати фінансові ресурси в інші країни. Вже у 60-ті роки виникли ринки єврооблігацій та ринки євроакцій, які функціонували за певними особливими угодами. Ринок цінних паперів у розвинутих країнах набуває значення основного джерела фінансових ресурсів, а значення банків у фінансуванні економіки зменшується.

Третій етап розпочався 3 1970-1980-х років, коли сформувався постійно функціонуючий ринок регулярних операцій міжнародних інвесторів, зосереджений у світових та регіональних фінансових центрах. Він характеризується глобальним характером комунікаційних зв'язків, виникненням нових інструментів, розширенням кола інвесторів [3].

На початку 2020 року загальна вартість всіх біржових акцій в світі не досягала і \$70. трлн. За рік вона зросла більш ніж на \$17 трлн. За оцінками аналітика з Deutsche Bank Торстена Слока, зараз сумарна ринкова капіталізація в усьому світі перевалила за $\$ 85$ трлн (рис.1.) [4].

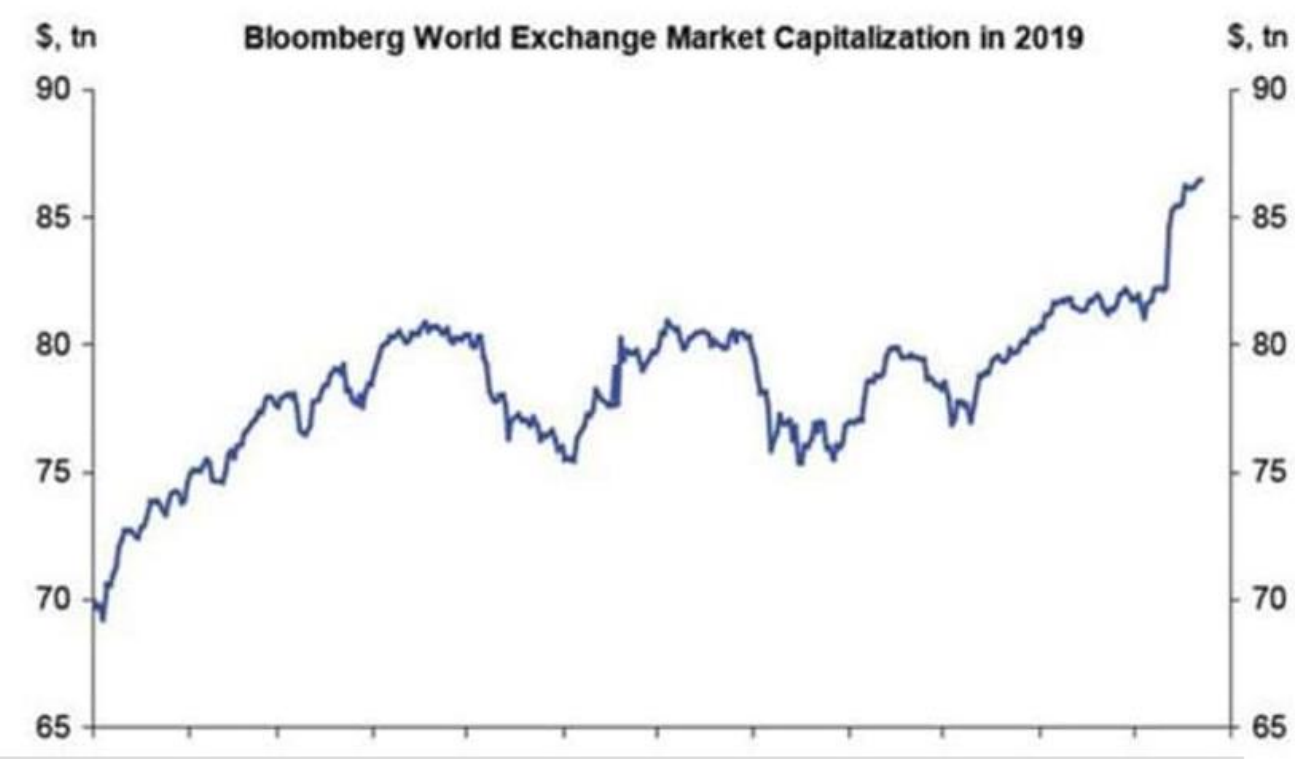

Рисунок 1 - Рівень капіталізації міжнародного фондового ринку в 2019

Джерело: [4]

Найбільше зростання відбулося на американському ринку акцій. Всі три провідні фондові індекси США виросли більш ніж на 20\%: Dow 
Jones Industrial піднявся на 22\%, S\&P 500 - на 28\%, NASDAQ - майже на $35 \%$.

Такі технологічні гіганти, як Apple i Facebook, подорожчали 3 початку року на $80 \%$ і $57 \%$ відповідно (рис. 2). Зростання акцій Apple навіть перевищив очікування. Поточна вартість паперів на 6,5\% перевершила прогноз аналітиків, опитаних Refinitiv. А у акцій Facebook $\epsilon$ значний потенціал зростання, вважають на Уолл-стріт. Згідно 3 опитуваннями Refinitiv, 47 з 52 аналітиків очікує подорожчання паперів в найближчому році. Середній потенціал зростання паперів становить $16,3 \%$.

Страхи інвесторів перед розповсюдженням коронавірусу привели до обвалу на ринках цінних паперів по всьому світу.

Ринок цінних паперів Британії впав на 10\% - це найстрімкіший обвал з 1987 року. У США різко впали індекси Dow Jones i S\&P 500, аналогічно до найгіршого показника з 1987-го [5].

Ситуація негативно відбилася не тільки на світових індексах, а й на стані мільярдерів 3 першої двадцятки рейтингу Forbes, яке, за підрахунками видання, всього за добу скоротилася на 40 млрд доларів.

Зокрема, найбагатша людина планети - глава Amazon Джефф Безос - втратив 4,8 млрд, гендиректор Facebook Марк Цукерберг - 3,4 млрд, а стан інвестора Уоррена Баффета скоротилися на 2,7 млрд доларів.

Однією $з$ найбільш обговорюваних подій на фондовому ринку цієї весни був обвал цін ф'ючерсів на нафту до від'ємного значення. Це сталося 20 квітня, вперше в історії.

Нафта WTI обвалилась до позначки «0» доларів на НьюЙоркській біржі, а потім знизилася до "мінус" 37 доларів за барель, що означає те, що падіння склало близько $300 \%$ (рис. 2-3).

Головні причини - коронавірус та порушення початкової угоди ОПЕК+. Після того, як Росія та Саудівська Аравія не домовилися продовжити угоду про скорочення видобутку, нафта подешевшала майже вдвічі. Через майже відсутній попит у світі багато невикористаної нафти, яку вже нема де зберігати.

У даному випадку мова йде про американську нафту марки WTI. У іншій частині світу ситуація не така катастрофічна. Ціна Brent впала тільки на 5\% до 26 дол за бар (рис. 3).

Через відсутність попиту на нафту все швидше закінчуються потужності для іiі зберігання, а припинити видобуток без значних втрат неможливо.

За словами виконавчого директора "Нафтогазу" Юрія Вітренка, при нинішніх темпах видобутку та споживання вже у листопаді 2020 року США повністю вичерпає можливість зберігати нафту власними силами. 


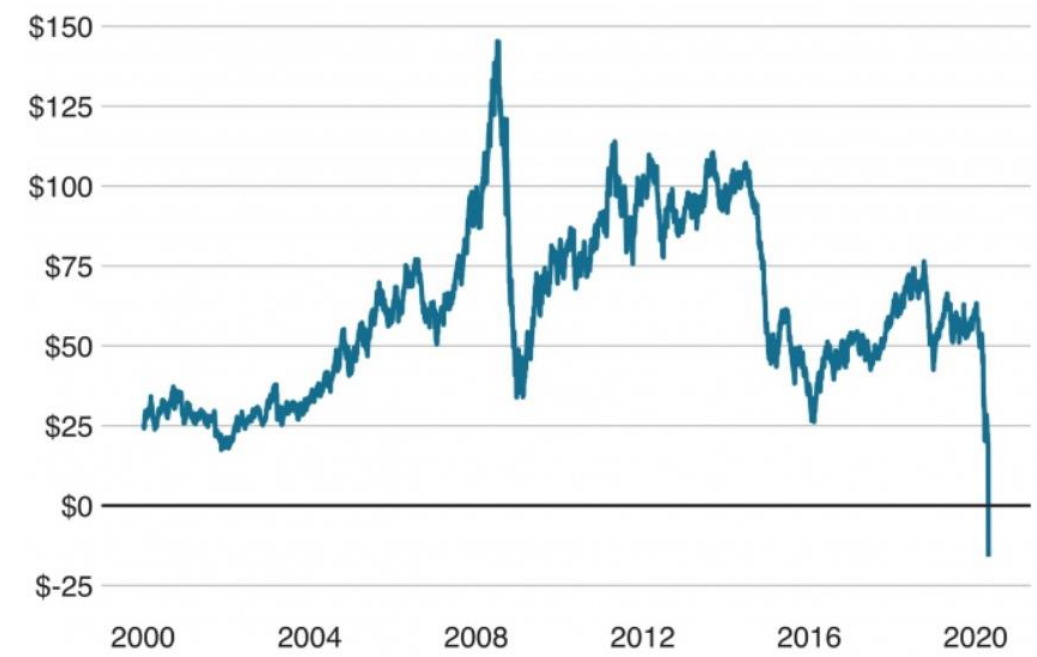

Рисунок 2 - Динаміка цін на нафту WTI за 2000-2020 pp. Джерело: [6]

В Україні є величезна нафтотранспортна система, де можна зберігати нафту, один працюючий завод (Кременчуцький НПЗ. - ЕП) iз значними потужностями для зберігання, а також багато нафтопереробних заводів, які давно зупинені, але на яких принаймні були такі ємкості. Тому бізнес із зберігання нафти зараз найбільш прибутковий.

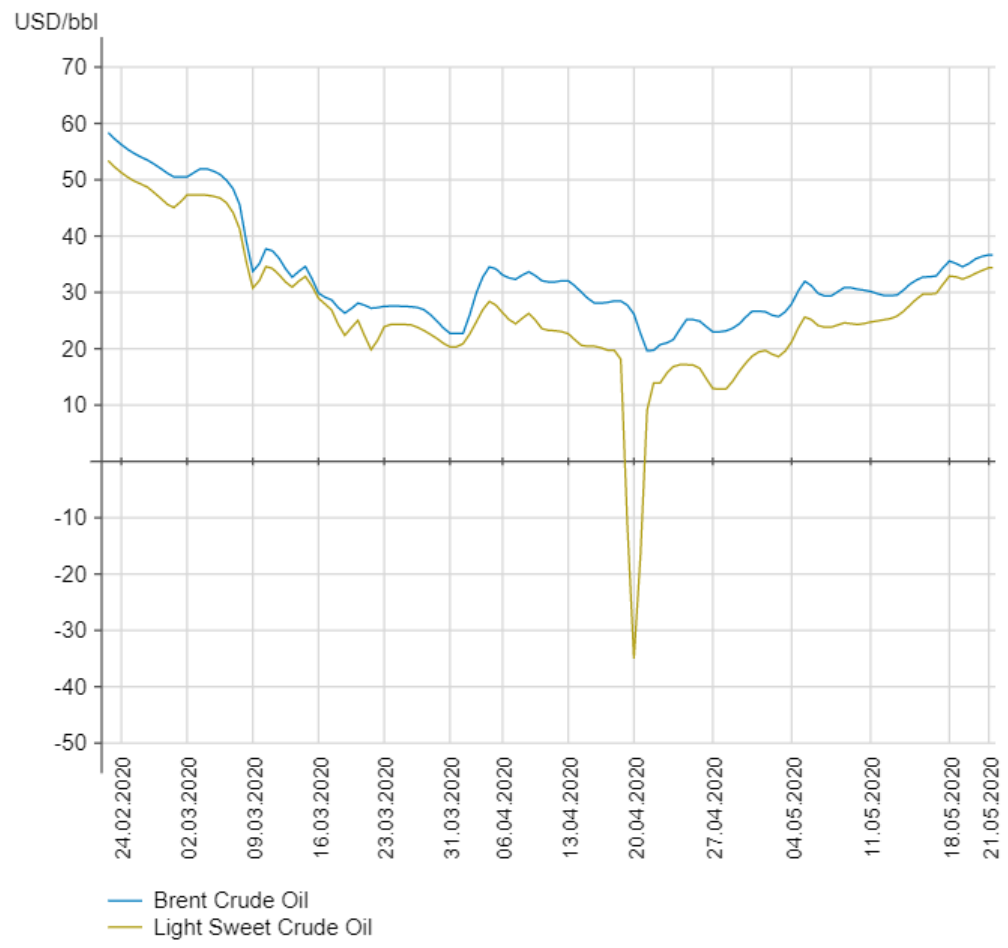

Рисунок 3 - Динаміка цін на нафту за лютий-травень 2020 р. Джерело: [7] 
Аналізуючи дані графіки, ми розуміємо, що на майбутнє повинна буде зменшитись ціна на нафтопродукти на вітчизнятих АЗС, проте, ми чітко повинні розуміти й те, що навіть, якщо ціна на нафту складатиме 0 , то ціна на дизель та бензин не зможуть бути нижчі певного рівня (рис 4.).

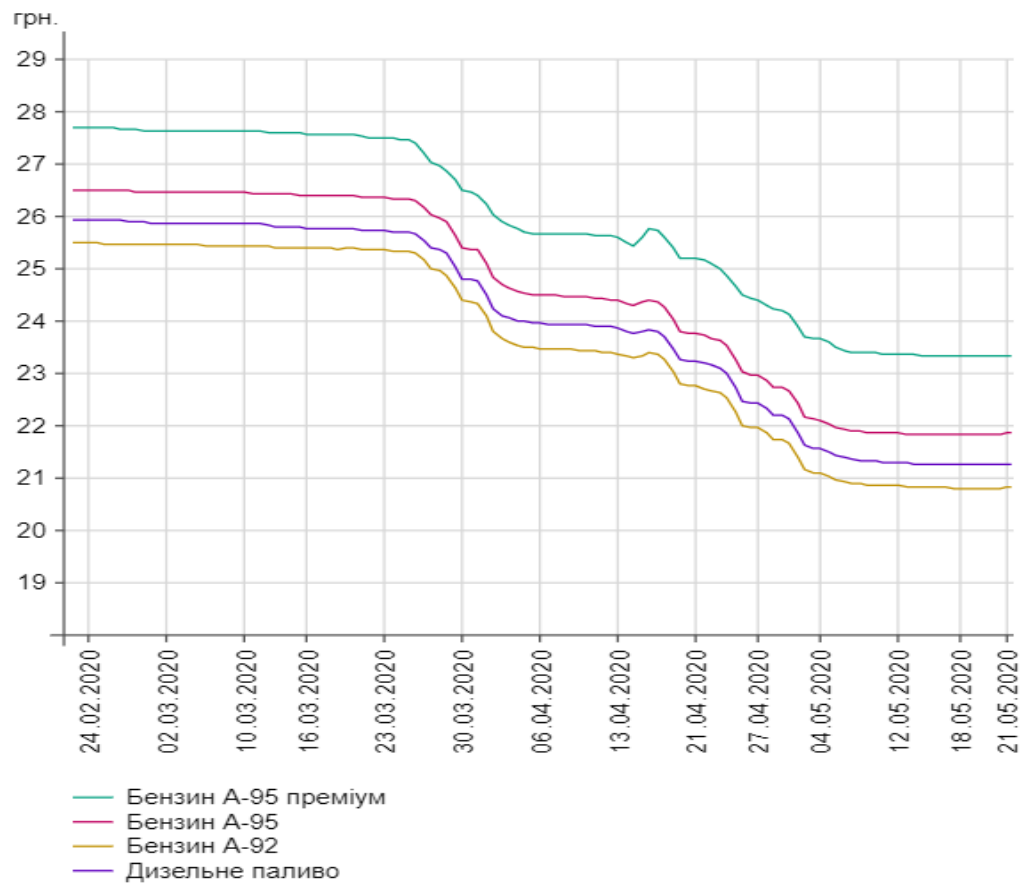

Рисунок 4 - Динаміка цін на бензин за лютий-травень 2020 p. Джерело: [8]

Так як карантинні заходи поступово скасовуються у всьому світі, ціна нафти почне поступово зростати. Але найчастіше нафту купують 3 договором про поставку на декілька місяців. Можемо зробити наступний висновок, що ціна на бензин та дизель повинні будуть зменшуватись, але не такими швидкими темпами, як сама нафта.

Для нашої держави $є$ позитивний момент, оскільки ми щороку імпортуємо паливно-мастильні матеріали на суму в 13 млрд доларів, а при умові, якщо ціни на них довго будуть на низькому рівні, це призведе до зміцнення курсу національної валюти та позитивного значення платіжного балансу. Проте, $є$ й друга сторона медалі, оскільки низькі ціни одразу вплинуть на прибутки вітчизняних енергетичних компаній, що призведе до недоотримання податків в бюджет.

Також ми розуміємо, що за падінням ціни на нафтопродукти слідує падіння на ринках металургійної та аграрної продукції, які $є$ основою нашого експорту.

У таблиці ми чітко бачимо те, що фізичні особи збільшили свій портфель 36 до 10 млрд. грн, проте через, зменшення облікової ставки НБУ з 18\% до 13,5\%, відбулось зменшення дохідності ОВДП. 
Таблиця - Середньозважені ставки дохідностей ОВДП

\begin{tabular}{|c|c|c|c|c|c|c|c|c|c|c|}
\hline \multirow{3}{*}{ Період } & \multirow{2}{*}{\multicolumn{2}{|c|}{$\begin{array}{c}\text { Розміщення на } \\
\text { первинному } \\
\text { ринку ОВДП, } \\
\text { номінованих у } \\
\text { гривні }\end{array}$}} & \multicolumn{4}{|c|}{ За терміном розміщення } & \multirow{2}{*}{\multicolumn{2}{|c|}{$\begin{array}{c}\text { Розміщення } \\
\text { на } \\
\text { первинному } \\
\text { ринку ОВДП, } \\
\text { номінованих } \\
\text { у іноземній } \\
\text { валюті (дол } \\
\text { США) } \\
\end{array}$}} & \multicolumn{2}{|c|}{$\begin{array}{c}\text { За } \\
\text { терміном } \\
\text { розміщення }\end{array}$} \\
\hline & & & $\begin{array}{l}\text { До } 1 \\
\text { року }\end{array}$ & $\begin{array}{c}1-3 \\
\text { роки }\end{array}$ & $\begin{array}{c}3-5 \\
\text { років }\end{array}$ & $\begin{array}{c}\text { Понад } \\
5 \\
\text { років }\end{array}$ & & & $\begin{array}{l}\text { До } 1 \\
\text { року }\end{array}$ & $\begin{array}{c}1-3 \\
\text { роки }\end{array}$ \\
\hline & 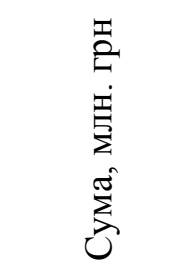 & 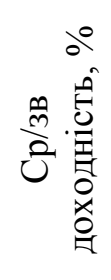 & 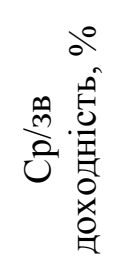 & 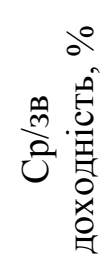 & 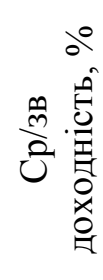 & 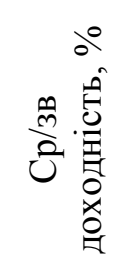 & 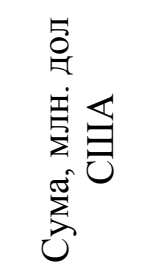 & 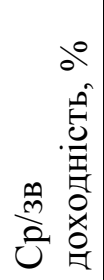 & 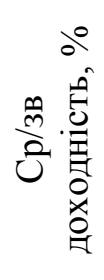 & 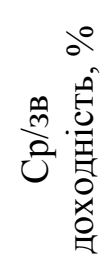 \\
\hline Січень & 24402,08 & 18,96 & 18,98 & 17,58 & - & - & 582,80 & 6,46 & 6,45 & 7,25 \\
\hline Лютий & 10349,48 & 19,20 & 19,30 & 17,94 & - & - & 302,69 & 6,60 & 6,55 & 7,40 \\
\hline Березень & 22731,14 & 18,76 & 19,24 & 18,02 & - & - & 159,77 & 7,00 & 6,59 & 7,72 \\
\hline Квітень & 55887,94 & 18,60 & 19,16 & 18,00 & 16,00 & - & 416,57 & 5,85 & 6,89 & 4,32 \\
\hline Травень & 12320,95 & 17,94 & 18,35 & 17,79 & 16,00 & - & 426,67 & 5,29 & 6,95 & 4,12 \\
\hline Червень & 17338,13 & 17,00 & 18,23 & 17,49 & - & 15,84 & 325,94 & 6,22 & 7,24 & 4,51 \\
\hline Липень & 45618,86 & 16,67 & 17,49 & 17,04 & - & 15,53 & 1005,65 & 6,69 & 6,50 & 7,00 \\
\hline Серпень & 7475,67 & 16,04 & 16,21 & 16,21 & - & 15,30 & - & - & - & - \\
\hline Вересень & 20691,27 & 15,12 & 15,78 & 15,72 & - & 14,75 & 546,89 & 5,41 & - & 5,41 \\
\hline Жовтень & 7966,17 & 15,09 & 15,08 & 14,90 & 15,42 & - & - & - & - & - \\
\hline Листопад & 10270,61 & 13,17 & 13,87 & 13,16 & 12,84 & - & 304,88 & 4,02 & - & 4,02 \\
\hline Грудень & 14499,51 & 11,62 & 11,86 & 11,57 & 11,59 & - & 258,97 & 3,70 & 3,40 & 3,91 \\
\hline $\begin{array}{l}\text { Всього за } \\
2019 \text { рік }\end{array}$ & 227551,81 & 16,93 & 18,40 & 16,73 & 13,11 & 15,31 & 4330,84 & 5,88 & 6,50 & 5,16 \\
\hline
\end{tabular}

Джерело: складено за даними [9].

Вважаємо, що надалі буде відбуватись зниження дохідності ОВДП, а також подальше зниження дохідності банківських депозитів та інших інструментів 3 фіксованою дохідністю, тому доцільним $є$ фіксація діючих ставок на максимальний термін в ОВДП.

Висновки. Проведене дослідження надало можливість визначити, що, міжнародний фондовий ринок - це невід'ємний інструмент перерозподілу капіталу в світі. Сучасні міжнародні ринки цінних паперів розвиваються у напрямку глобалізації, інституціоналізації, технологізації, скорочення кількості фондових бірж до однієї для країни, дематеріалізації та електронного обігу цінних паперів тощо. Капіталізація міжнародного фондового ринку зросла на \$17 трлн. за 2019 рік.

В Україні спостерігається тенденція до зниження доходності державних облігацій. Стрімко розвивається інтернет-трейдинг на світових біржах. У 2019 вперше почали надавати онлайн доступ до торгів на Українській біржі. 
Наукова новизна одержаних результатів полягає у дослідженні впливу пандемії COVID-19 на ситуацію на міжнародному фондовому ринку.

Одним 3 найбільш яскравих показників обвалу $\epsilon$ зниження вартості ф'ючерсів на нафту до від'ємного значення. Тому Україна може використати свої можливості для зберігання нафти світової арени 3 метою отримання прибутку.

\section{Література:}

1. Д'яконова I. I. Удосконалення банківських операцій і попередження ризиків як умова зміцнення банківської системи України : монографія / І. Д’яконова. Суми : Університетська книга, 2007. 88 с.

2. Duff \& Phelps' (2019). Global Regulatory Outlook Report // [Електронний ресурс]. Режим д доступу : https://www.duffandphelps.com//media/assets/pdfs/publications/compliance-and-regulatory-consulting/globalregulatory-outlook-2019.pdf (дата доступу 14.04.2020).

3. Базилевич В.Д. Концентрація у банківському секторі України: сучасний стан та шляхи регулювання // Банківська справа. 2012. № 2. С. 3-18

4. Jesse Pound. (2019). Global stock markets gained $\$ 17$ trillion in value in $2019 / /$ [Електронний ресурс]. Режим доступу : https://www.cnbc.com/2019/12/24/globalstock-markets-gained-17-trillion-in-value-in-2019.html (дата доступу 14.04.2020).

5. Elaine Kurtenbach (2020). Asian shares plunge after Wall Street's worst day since '87. // [Електронний ресурс]. Режим доступу : https://apnews.com/f4dec5de0bcb4d32a1e28ada66e2fc6f?utm_campaign=SocialFlow \&utm_medium=AP\&utm_source=Twitter (дата доступу 14.04.2020).

6. ВBC (2020). US oil prices turn negative as demand dries up. // [Електронний ресурс]. Режим доступу : https://www.bbc.com/news/business-52350082 (дата доступу 14.04.2020).

7. Мінфін. Ціна нафти за 2020 // [Електронний ресурс]. - Режим доступу : https://index.minfin.com.ua/ua/markets/oil/ (дата доступу 14.04.2020).

8. Мінфін. Ціна бензину за 2020 // [Електронний ресурс]. Режим доступу : https://index.minfin.com.ua/ua/markets/fuel/ (дата доступу 14.04.2020).

9. Національний банк України.Дохідність ОВДП на первинному ринку (2020) // [Електронний ресурс]. Режим доступу : https://bank.gov.ua/files/OVDP_mis.xlsx (дата доступу 14.04.2020).

10. Розвиток банківської системи України як основа реалізації стратегії економічного зростання [Текст]: монографія / за ред. Д.е.н., проф. О. В. Дзюблюка. Тернопіль: ТНЕУ, 2010. 384 с.

\section{References:}

1. D'iakonova, I. I., (2007), Udoskonalennia bankivs'kykh operatsij i poperedzhennia ryzykiv iak umova zmitsnennia bankivs'koi systemy Ukrainy [Improvement of banking operations and risk prevention as a condition for strengthening the banking system of Ukraine], Universytets'ka knyha, Sumy, Ukraine.

2. Duff \& Phelps', (2019), "Global Regulatory Outlook Report", Available at: https://www.duffandphelps.com/-/media/assets/pdfs/publications/compliance- andregulatory- consulting/global- regulatory- outlook- 2019.pdf (Accessed 14.04.2020). 
3. Bazylevych, V.D., (2012), "Concentration in the banking sector of Ukraine: current state and ways of regulation", Bankivs'ka sprava, vol 2, pp. 3-18.

4. Jesse Pound, (2019), "Global stock markets gained \$17 trillion in value in 2019", Available at: https://www.cnbc.com/2019/12/24/global-stock-markets-gained-17trillion-in-value-in-2019.html (Accessed 14.04.2020).

5. Elaine Kurtenbach, (2020), “Asian shares plunge after Wall Street's worst day since '87", Available at: https://apnews.com/f4dec5de0bcb4d32a1e28ad a66e2fc6f?utm_campaign=SocialFlow\&utm_medium=AP\&utm_source=Twitter (Accessed 14.04.2020).

6. BBC, (2020), "US oil prices turn negative as demand dries up" Available at: https://www.bbc.com/news/business-52350082 (Accessed 14.04.2020).

7. Minfin, (2020), “Tsina nafty za 2020" Available at: https://index.minfin.com.ua/ua/markets/oil/ (Accessed 14.04.2020).

8. Minfin, (2020), “Tsina benzynu za 2020" Available at: https://index.minfin.com.ua/ua/markets/fuel/ (Accessed 14.04.2020).

9. Natsional'nyj bank Ukrainy, (2020), "Dokhidnist' OVDP na pervynnomu rynku", Available at: https://bank.gov.ua/files/OVDP_mis.xlsx (Accessed 14.04.2020).

10. Dziubliuk, O. V. (2020), Rozvytok bankivs'koi systemy Ukrainy iak osnova realizatsii stratehii ekonomichnoho zrostannia [Development of the banking system of Ukraine as a basis for the implementation of economic growth strategy], TNEU, Ternopil', Ukraine.

УДК 339.9

JEL classification: F13, F53, O19

Редько К.Ю.

канд. економ. наук

ORCID ID: 0000-0003-2609-3471

Голембіовська Ю. Ю.

ORCID ID: 0000-0002-9911-968X

Національний технічний університет Украӥни «Київський політехнічний інститут імені Ігоря Сікорського»

\section{ТРАНСФОРМАЦІЯ СТРУКТУРИ УКРАЇНСЬКОЇ ЕКОНОМІКИ ЗАВДЯКИ ЧЛЕНСТВУ У СВІТОВІЙ ОРГАНІЗАЦЇ̈ ТОРГІВЛІ}

\section{TRANSFORMATION OF THE STRUCTURE OF THE UKRAINIAN ECONOMY THANKS TO MEMBERSHIP IN THE WORLD TRADE ORGANIZATION}

\footnotetext{
Статтю присвячено вступу України до СОТ, особливо - наслідкам изього процесу для національної економіки. Автори дають оцінку потениійним перевагам та втратам від вступу України до иієї міжнародної організації. У статті охарактеризовано розвиток галузей та підгалузей в умовах членства Украӥни в СОТ. Проведене дослідження, щодо структури та динаміки складових ВВП та зовнішньоторговельних показників за період 2007-2019 років, дозволило оцінити
} 